\title{
Virus infections in Nordic honey bee colonies with no, low or severe Varroa jacobsoni infestations
}

\author{
Sanna Nordström ${ }^{\mathrm{a} *}$, Ingemar Fries ${ }^{\mathrm{a}}$, Aasne Aarhus ${ }^{\mathrm{b}}$, \\ Henrik Hansen ${ }^{c}$, Seppo Korpela ${ }^{d}$ \\ ${ }^{a}$ Swedish University of Agricultural Sciences, Department of Entomology, \\ P.O. Box 7044, S-750 07 Uppsala, Sweden \\ b Agricultural University of Norway, Department of Animal Science, \\ P.O. Box 5025, N-1432 Ås, Norway \\ c Danish Institute of Agricultural Sciences, Research Group Entomology, \\ Research Center Flakkebjerg, DK-4200 Slagelse, Denmark \\ d Agricultural Research Center of Finland, Plant Production Research, \\ Plant Protection, SF-31 600 Jokioinen, Finland
}

(Received 5 March 1999; revised 1 August 1999; accepted 18 August 1999)

\begin{abstract}
Honey bee viruses in Apis mellifera colonies were studied at eight Nordic locations with disparate Varroa jacobsoni infestations. Cloudy wing virus (CWV) was the most prevalent infection in all apiaries irrespective of mite infestation. Detection of CWV was not associated with colony collapse in this study. In one apiary where colonies collapsed, deformed wing virus (DWV) was detected. When certain mite mortality levels were reached in this apiary, both live and dead bee samples were always positive for DWV. However, colonies with low values of mite mortality could also be positive for DWV, and this virus could be detected several weeks before colony death in some cases. In the second apiary with collapsing colonies acute paralysis virus (APV) was detected in a live bee sample from one colony, close to the time of colony collapse. The following viruses were detected for the first time in the respective countries, CWV: Denmark, Norway and Sweden; BQCV: Denmark; DWV: Sweden. (CInra/DIB/AGIB/Elsevier, Paris
\end{abstract}

Apis mellifera / virus infection / Varroa jacobsoni / colony collapse / deformed wing virus

\footnotetext{
* Correspondence and reprints

E-mail: susann.nordstrom@entom.slu.se
} 


\section{INTRODUCTION}

In recent years, it has become apparent that the devastating effect of the parasitic mite Varroa jacobsoni in colonies of the European honey bee Apis mellifera is closely linked to virus infections [2]. At present, we know of no honey bee colonies in Europe where the mite population can be left to develop freely without a lethal effect on the colony.

Since the early 1960 s several honey bee viruses have been isolated and at present 15 different viruses are known to infect A. mellifera $[2,5]$. Some of these viruses are known, or suspected, to be associated with infestations of $V$. jacobsoni $[2,8,10$, 11]. In both Russia and Germany the occurrence of acute paralysis virus (APV) in dead field bees and brood has been associated with mite infestations $[9,12]$. APV has also been detected in individual mites [3]. In studies of severely infested colonies in Germany the adult bee and brood population declined at the end of summer, primarily as a result of APV infection [11] and APV has now been found as an overt infection in severely mite-infested honey bee colonies in several countries $[2,15]$. APV has, however, never been found as a cause of honey bee mortality in the field without simultaneous infestation by $V$. jacobsoni $[2,6]$.

Recently, the increased occurrence of bees with non-developed or deformed wings in mite-infested colonies has been associated with deformed wing virus (DWV) infection [13]. This virus has been found in severely mite-infested colonies in Europe, Africa and Asia [2] and has been linked to the collapse of mite-infested colonies in the United Kingdom [17].

There are few detailed studies on the prevalence and incidence of viruses in honey bee colonies in different countries [2] and the information on virus prevalence in the Nordic countries is limited. In Finland one study was undertaken in 1989 [19] and in the other Nordic countries (Sweden, Den- mark and Norway) only occasional samples of dead bees have been analysed for viruses [2].

The aim of this study was to investigate the prevalence of honey bee virus infections in $A$. mellifera colonies with no, low or severe $V$. jacobsoni infestation in eight apiaries distributed throughout the Nordic countries. At two locations virus prevalence was determined as mite populations developed from initially low infestations up to colony collapse.

\section{MATERIALS AND METHODS}

\subsection{Bee colonies and sampling}

During 1994 two experimental apiaries comprising a total of 13 colonics were established where mite populations were allowed to develop freely up to colony collapse. One apiary in Denmark (Skoven) comprised five colonies moved from a non-infested area and placed among infested colonies in May 1994. The other apiary was on the Baltic island of Gotland in Sweden and comprised four mite-free colonies which were moved in May 1994 from a non-infested apiary (Uppsala) on the mainland into an apiary with four infested colonies. No mite control was employed during the study period in these two apiaries.

Six other apiaries in Denmark $(n=1)$, Finland $(n=3)$, Norway $(n=1)$ and Sweden $(n=1)$ were also included in this study, all with no or low mite infestations. The Danish apiary Højbakke was originally mite-free, the first mites were detected in March 1995 and colonies were treated for the first time in August 1996. Initially all Finnish colonies had low numbers of mites and mite populations were controlled throughout the experimental period. In the Norwegian apiary the first few mites were detected in September 1994. The Swedish apiary in Uppsala was not infested, and was still considered free of mites als of March 1999.

All experimental colonies $(n=42)$ in all eight apiaries were equipped with screen bottoms that allowed monitoring of natural mite mortality. Samples of approximately 200 live adult bees were taken directly from the brood combs every month during the active season, and bees that died during winter were collected from the bot- 
tom board in early spring for analysis for viruses. In the Swedish apiary on Gotland, samples of dead bees were also collected from May to October 1995 using a dead bee trap modified after Bailey [4]. The natural mite mortality was determined by counting dead mites on screen bottom boards in all colonies every 8-9 days, except for the two Danish apiaries where dead mites were counted once a month. In total, 411 bee samples were tested serologically for the presence of nine different viruses and investigated for the microsporidian Nosema apis and the protozoan Malpighamoeba mellificae, which have both been associated with certain viruses [7].

\subsection{Sample preparation}

Live bee samples were extracted as follows: 60 bees were homogenized on ice in thick glass tubes in $6 \mathrm{~mL} 0.01 \mathrm{M} \mathrm{KH}_{2} \mathrm{PO}_{4} \mathrm{pH} 6.7$ with $0.02 \%$ diethyl dithio-carbamic acid (DIECA) using an Ultra-lurrax homogenizer (Ika laboratories). The homogenate was vigorously shaken with $2 \mathrm{~mL} \mathrm{CCl}_{4}$ until an emulsion was formed and cleared at $12000 \mathrm{~g}$ for $10 \mathrm{~min}$ at $4{ }^{\circ} \mathrm{C}$ in a Sorval centrifuge. The pellet was examined for $N$. apis spores and $M$. mellificae cysts. To the supernatant $0.5 \mathrm{~mL} \mathrm{CCl}_{4}$ was added and thereafter left at $4{ }^{\circ} \mathrm{C}$ overnight. After mixing, the extract was centrifuged at $10000 \mathrm{~g}$ for $5 \mathrm{~min}$ at $4{ }^{\circ} \mathrm{C}$ and the supernatant $(6-10 \mathrm{~mL})$ was used directly in serological tests. In contrast to similar studies $[6,11,14,19]$ this sample preparation included no ultracentrifugation step.

The number of bees analysed from samples of dead bees collected in traps varied between 10 and 60 bees, and these samples were homogenized in $1 \mathrm{~mL} 0.01 \mathrm{M} \mathrm{KH}_{2} \mathrm{PO}_{4}$ buffer per ten bees, otherwise the procedure was the same as for live bee samples.

\subsection{Serology}

Samples were tested by immunodiffusion [16, 18] against antisera to acute paralysis virus (APV), black queen cell virus (BQCV), sacbrood virus (SBV), chronic paralysis virus (CPV), bee virus $X(B V X)$, bee virus $Y(B V Y)$ and slow paralysis virus (SPV) in EDTA gel plates (50 $\mathrm{mM} \mathrm{KH}_{2} \mathrm{PO}_{4}$ pH 6.7, 5 mM EDTA, $0.02 \%$ $\mathrm{NaN}_{3}$ and $0.75 \%$ agar). Tests for deformed wing virus (DWV) and cloudy wing virus (CWV) were made in gel plates with a higher salt content $\left(0.2 \mathrm{M} \mathrm{KH}_{2} \mathrm{PO}_{4} \mathrm{pH} 8.0,0.01 \% \mathrm{KCl}, 0.02 \%\right.$ $\mathrm{NaN}_{3}$ and $0.75 \%$ agar). Serological tests for APV were performed in Uppsala, Sweden, with a polyclonal antiserum developed to an American (Florida) isolate of APV. This antiserum was found to be APV specific at IACR-Rothamsted, UK, with the highest titre ( $1 / 1024)$ to the original American isolate, a titre of $1 / 512+$ to the British type strain [1], and had no non-specific reactions to bee protein. The samples were frozen at $-22{ }^{\circ} \mathrm{C}$ and analysis for the other eight virus types were carried out at IACR-Rothamsted.

\section{RESULTS}

Seven out of eight colonies in the Swedish apiary on Gotland died within 2 years of no treatment for $V$. jacobsoni. The mite populations increased over time but varied between colonies within this apiary and there was a significant difference in the natural mite mortality data between the original Gotland colonies and the colonies which were moved to the apiary from Uppsala (figure $1 a$ ). In mid August 1995, the mean mite mortality in individual colonies varied between five and 100 mites per day. In 40 samples of live bees from 1994 the only virus detected in this apiary was CWV in September in one colony (no. 4) (table I). During the last year of sampling, DWV was found at least once in dead bee samples in all eight colonies and in live bee samples from three colonies (table $I I$ ). DWV was first detected in colonies originating from Gotland (table II). The only other virus detected in 1995 in the Gotland apiary was CWV, in samples from three colonies (table $I I$ ). In figure 2 , the mean mite mortality data from the Gotland apiary recorded at the time of bee sampling is plotted against samples positive and negative for DWV, respectively. The figure illustrates that colonies with low values of mite mortality could be positive for DWV, whereas when certain mite levels were reached, the samples were always positive for DWV in this apiary.

In the Danish apiary at Skoven, all five colonies died within 2 years of the initial 

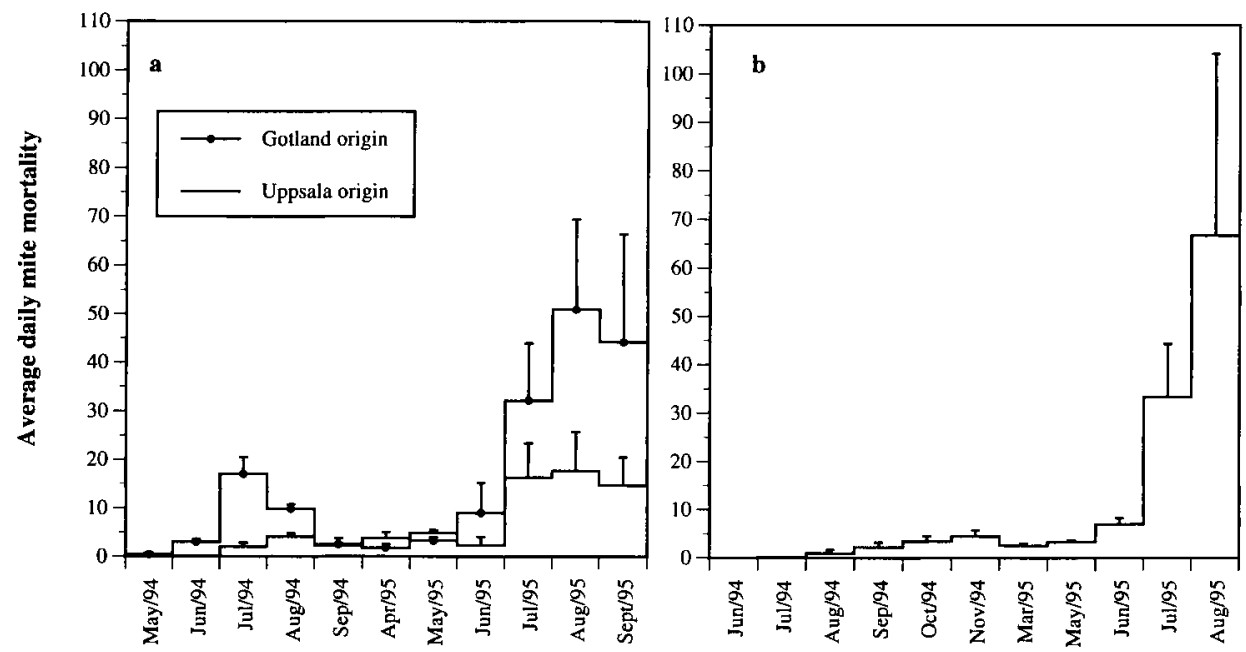

Figure 1. Development of $V$. jacobsoni populations in collapsing colonies in two apiaries measured as average daily natural mite mortality. Vertical bars show standard error of the means. a) Gotland, Sweden, $n=8$; b) Skoven, Denmark, $n=5$.

Table I. The distribution of study colonies, number of sampled colonies, period of sample collection, if live or dead bees were sampled, number of analysed samples, number of samples with a positive reaction in immunodiffusion tests and viruses detected in each apiary.

\begin{tabular}{|c|c|c|c|c|c|c|}
\hline Apiary & $\begin{array}{l}\text { Sampled } \\
\text { colonies }\end{array}$ & $\begin{array}{l}\text { Collection } \\
\text { period }\end{array}$ & $\begin{array}{c}\text { Bee } \\
\text { sample }\end{array}$ & $\begin{array}{l}\text { Number of } \\
\text { samples }\end{array}$ & $\begin{array}{l}\text { Samples } \\
\text { positive }\end{array}$ & $\begin{array}{c}\text { Virus } \\
\text { detected }\end{array}$ \\
\hline Uppsala, Sweden & 4 & $\begin{array}{l}\text { 1994: June-Sep. } \\
\text { 1995: June-Sep. }\end{array}$ & $\begin{array}{l}\text { live } \\
\text { live }\end{array}$ & $\begin{array}{l}16 \\
12\end{array}$ & $\begin{array}{l}0 \\
0\end{array}$ & $\begin{array}{l}- \\
-\end{array}$ \\
\hline Asker, Norway & 10 & 1994: May-Sep. & live & 30 & 5 & CWV \\
\hline SML/S, Finland & 2 & 1994: May-Nov. & live & 14 & 7 & CWV \\
\hline MTT, Finland & 4 & $\begin{array}{l}\text { 1994: May-Nov. } \\
\text { 1995: May-Nov. }\end{array}$ & $\begin{array}{l}\text { live } \\
\text { live }\end{array}$ & $\begin{array}{l}28 \\
28\end{array}$ & $\begin{array}{l}7 \\
0\end{array}$ & $\begin{array}{c}\mathrm{CWV} \\
-\end{array}$ \\
\hline Højbakke, Denmark & k 5 & $\begin{array}{l}\text { 1994: May-Oct. } \\
\text { 1995: Mar. } \\
\text { 1996: Mar. } \\
\text { 1996: Sep-Oct. }\end{array}$ & $\begin{array}{c}\text { live } \\
\text { winter dead } \\
\text { winter dead } \\
\text { live }\end{array}$ & $\begin{array}{c}30 \\
5 \\
5 \\
10\end{array}$ & $\begin{array}{l}5 \\
2 \\
0 \\
0\end{array}$ & $\begin{array}{c}\text { CWV } \\
\text { CWV, BQCV } \\
- \\
-\end{array}$ \\
\hline SML/E, Finland & 4 & $\begin{array}{l}\text { 1994: May-Nov. } \\
\text { 1995: Aug,-Nov. }\end{array}$ & $\begin{array}{l}\text { live } \\
\text { live }\end{array}$ & $\begin{array}{l}28 \\
14\end{array}$ & $\begin{array}{l}2 \\
1\end{array}$ & $\begin{array}{l}\text { CWV } \\
\text { CWV }\end{array}$ \\
\hline Gotland, Sweden* & 8 & $\begin{array}{c}\text { 1994: May-Sep. } \\
\text { 1995: May-Dec. } \\
\text { 1995: May-Dec. } \\
\text { 1996: Mar. }\end{array}$ & $\begin{array}{c}\text { live } \\
\text { live } \\
\text { dead } \\
\text { winter dead }\end{array}$ & $\begin{array}{c}40 \\
49 \\
33 \\
3\end{array}$ & $\begin{array}{c}1 \\
9 \\
11 \\
2\end{array}$ & $\begin{array}{c}\text { CWV } \\
\text { DWV, CWV } \\
\text { DWV, CWV } \\
\text { DWV }\end{array}$ \\
\hline Skoven, Denmark* & 5 & $\begin{array}{l}\text { 1994: May-Oct. } \\
\text { 1995: Mar. } \\
\text { 1995: May-Oct. } \\
\text { 1996: May }\end{array}$ & $\begin{array}{l}\text { live } \\
\text { winter dead } \\
\text { live } \\
\text { live }\end{array}$ & $\begin{array}{c}30 \\
5 \\
30 \\
1\end{array}$ & $\begin{array}{l}6 \\
1 \\
2 \\
0\end{array}$ & $\begin{array}{c}\text { CWV } \\
\text { CWV } \\
\text { APV, BVX } \\
-\end{array}$ \\
\hline
\end{tabular}

\footnotetext{
* Apiaries with collapsing colonies.
} 
Table II. Detection of DWV, by immunodiffusion, in honey bee samples $(n=85)$ collected during 1995-1996 from eight colonies in a $V$. jacobsoni-infested apiary in Gotland, Sweden. A missing sample is denoted s.m. Colonies 1-4 were moved to Gotland from an uninfested area (Uppsala) in May 1994. Colony 7 was dead by 4 October, colonies 1, 2, 4 and 6 were dead by 4 December, and colonies 3 and 8 died early 1996. Colony 5 survived. Detection of CWV is also given.

\begin{tabular}{|c|c|c|c|c|c|c|c|c|c|}
\hline \multirow[t]{2}{*}{ Date } & \multirow{2}{*}{$\begin{array}{l}\text { Bee } \\
\text { sainple }\end{array}$} & \multicolumn{8}{|c|}{ Colony no. } \\
\hline & & $1^{\mathrm{H}}$ & $2^{\prime \prime}$ & $3^{u}$ & $4^{u}$ & $5^{g}$ & $6^{\mathrm{g}}$ & $7 \mathrm{~g}$ & $8^{g}$ \\
\hline 3 May 1995 & live & - & - & - & - & - & - & - & - \\
\hline 3 May 1995 & dead & - & - & - & - & - & - & $-^{*}$ & - \\
\hline 30 May 1995 & live & - & - & - & $-^{*}$ & - & - & - & - \\
\hline 30 May 1995 & dead & - & - & s.m. & - & - & - & - & - \\
\hline 7 July 1995 & live & - & - & $-^{*}$ & $-^{*}$ & - & - & - & - \\
\hline 30 July 1995 & live & - & - & - & $-*$ & - & - & - & - \\
\hline 30 July 1995 & dead & s.m. & s.m. & s.m. & s.m. & s.m. & - & + & s.m. \\
\hline 29 August 1995 & live & - & - & - & - & - & + & + & - \\
\hline 29 August 1995 & dead & s.m. & s.m. & s.m. & - & - & + & + & + \\
\hline 7 September 1995 & live & s.m. & s.m. & s.m. & s.m. & s.m. & + & + & s.m. \\
\hline 4 October 1995 & live & - & - & - & + & - & - & & - \\
\hline 4 October 1995 & dead & - & + & - & - & - & - & + & + \\
\hline 4 December 1995 & dead & + & s.m. & s.m. & + & s.m. & + & & s.m. \\
\hline March 1996 & dead & & & + & & + & & & - \\
\hline
\end{tabular}

+ Sample with a positive reaction to DWV antiserum; - sample with a negative reaction to DWV antiserum.

* Sample with a positive reaction to CWV antiserum.

infestation of $V$. jacobsoni. This apiary was severely mite infested and the variability in natural mite mortality within the apiary was large (figure $1 b$ ). In mid August 1995, the mean mite mortality in individual colonies in the Skoven apiary varied between four and 159 mites per day. One colony was dead by August 1995, and live bees sampled a few days before total collapse contained APV. In the other four dying colonies no virus was detected in live bee samples during 1995, except for BVX in one sample collected in May (table I). In 30 samples from 1994, CWV was found in live bees from one colony from May to October (table I). In addition to this, CWV was detected in one sample of dead bees from the winter 1994/1995.

No damage or symptom of disease could be seen in any of the apiaries that had naturally low numbers of mites or were unin- fested. CWV was commonly detected in live bee samples from five of these apiaries (table I). Two Finnish apiaries (MTT and SML/S) each had one colony with live bee samples positive for CWV in every sample taken from May to November 1994. The natural mite mortality never rose above four mites per day in these two apiaries. In August 1995 the mean daily mite mortality in the Finnish apiary SML/E peaked at 17 $(n=4 ; \mathrm{SE}=9.4)$. In the Norwegian apiary (Asker) live bee samples from one colony were positive for CWV from May to July 1994. In Asker the mean mite mortality was only $0.007(n=10 ; \mathrm{SE}=0.0001)$ mites per day in September 1994. In the second Danish apiary (Højbakke) CWV was found in five live bee samples collected in 1994 from one colony and in dead winter bees from the same colony. No CWV was, however, detected in samples collected during 1996 


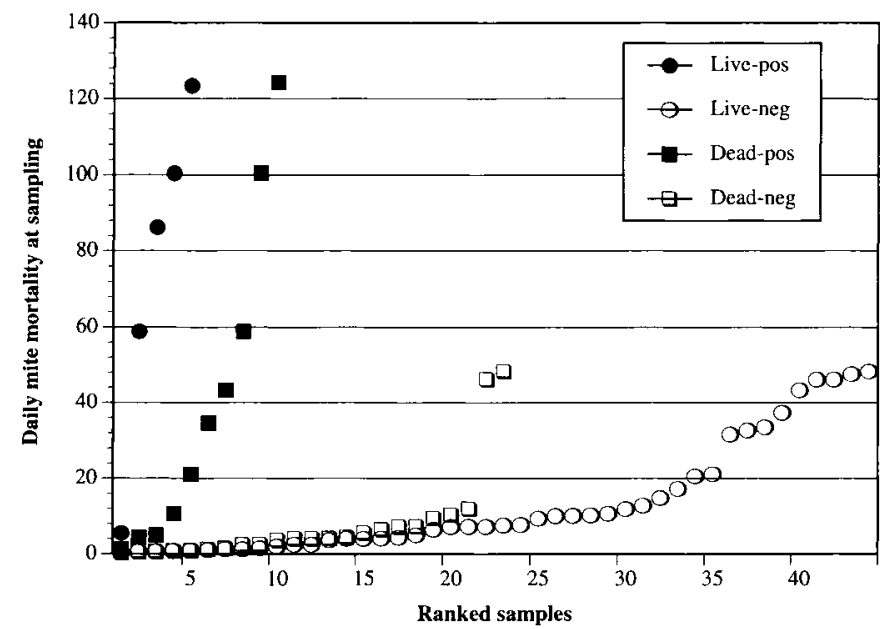

Figure 2. Ranked samples, positive or negative for DWV in immunodiffusion in relation to average daily $V$. jacobsoni mortality for each sampling occasion in the apiary on Gotland, Sweden in 1995. Samples are ranked according 10 mite mortality at sampling, starting with the lowest value. Live and dead adult bee samples are shown separately. The total number of samples are 82 from cight different colonies. from the same colony. Bees that died during winter (1994/1995) from another colony in Højbakke had a positive reaction against BQCV antiserum but contained no N. apis spores. In August 1996 the mean mite mortality in Højbakke was $8.6(n=5 ; \mathrm{SE}=1.4)$ mites per day. In the apiary without mites (Uppsala, Sweden), no virus was detected in 28 samples of live bees.

Thus, this study has added the following viruses to the list of honey bee viruses detected in honey bees from the Nordic countries: Denmark: CWV, BQCV; Finland: nil; Norway: CWV; Sweden: DWV, CWV.

$N$. apis spores were found at irregular intervals throughout the sampling period in bee samples from all apiaries and $M$. mellificae was not found in any of the samples.

\section{DISCUSSION}

We found DWV associated with colony collapse in one apiary (Gotland). In the other severely infested apiary, the only virus detected in connection with colony death was APV (Skoven). The results from the study by Ball and Allen [11] suggested that APV may be a primary cause of mortality in honey bee colonies severely infested by
V. jacobsoni in Germany. In the United Kingdom, however, APV has rarely been detected in connection with colony collapse. Recent British studies have shown that severely mite-infested colonies may die from SPV or DWV infections, and indicate a higher prevalence of CWV $[10,17]$. Hence, various virus types seem to be able to develop into acute infections in mite-infested colonies. Why one virus type appears and not another in specific cases may to some extent be explained by restricted virus distribution.

In this study in one of the apiaries where colonies collapsed, DWV was detected in every colony on some occasion, and in some of the colonies this virus was detected in live bee samples several weeks or even months before total collapse. This indicates that DWV infections may be important to explain bee mortality in colonies severely infested with $V$. jacobsoni. A large mite population appeared to be associated with the detection of DWV in live bee samples in this study. However, a large mite population size, based on mite mortality data, did not seem to be necessary for detection of DWV in dead bee samples. The detection of DWV in dead bee samples from collapsing colonies corroborates the data of Martin 
et al. [17]. The fact that this virus was also detectable by immunodiffusion in live bee samples indicates that this infection may be overt in honey bee colonies long before colony collapse.

Although there is a correlation between DWV infections and colony collapse in this study and other studies [17], the causal relationship between this virus and colony death remains to be verified. From the data in the apiary infected with DWV, it seems as if this virus may be detected in colonies with small mite populations when the virus infection has spread within the apiary, whereas the virus infection is always detectable once the natural mite mortality reaches certain levels; above 50 mites per day in this particular case (figure 2). It may be hypothesized that if large mite populations trigger severe virus infections in some colonies, these infections may spread within the apiary also to colonies with smaller mite populations. This is supported by the detection of DWV in $V$. jacobsoni [13] and by the fact that DWV was first detected in colonies with high mite mortality in the Gotland apiary in this study. Likewise, in a British study, SPV was first detected in colonies with large mite populations and 1 month later in colonies with smaller mite populations within the same apiary [10].

In the second apiary with severe mite infestations (Skoven), APV was only detected in one of the collapsing colonies. No virus was detected in live bee samples from the remaining four dying colonies. However, a negative result does not necessarily denote a virus-free colony and no dead bee samples were analysed.

In colonies with low or no mite infestations the only viruses found were CWV and BQCV. CWV is a common virus of honey bees [5] and in this study CWV was detected in seven out of eight apiaries. Five of these apiaries had at least one colony with live bees carrying detectable amounts of this virus at every sampling occasion in 1994 (table I). In Britain and Finland CWV has been detected in about $27 \%$ of dead bee samples $[6,19]$, in this study about $10 \%$ (37 out of 360 ) of the samples of live bees were positive for CWV. Apparently it is possible to detect $\mathrm{CWV}$ in live bee samples using the described detection method, and, evidently, a colony can have many bees with an overt CWV infection and still persist. In this investigation detection of CWV in live bee samples was independent of mite population size, and CWV was not detected in close connection to colony collapse.

For interpretation of the results it is important to consider the sensitivity and the limitation of the virus detection method used. For a positive reaction in immunodiffusion an overt virus infection is probably needed [5], consequently when sampling live bees, a significant proportion of the live bees should be infected. Live bee samples represent a small proportion of the total bee population in a colony and a virus infection is likely to be well established in the population if it is detected in live individuals by immunodiffusion. Furthermore, for detection of DWV and CWV, samples are usually extracted in a more concentrated buffer at a higher $\mathrm{pH}$ than in our study [5]. Extraction in a more appropriate buffer may have given a higher yield of the two viruses; therefore, all samples positive for DWV and CWV antisera may not have been detected.

A deeper understanding of how a virus infection develops in a $V$. jacobsoni-infested colony may have implications for treatment or management strategies. Today is it difficult to quantify the influence of virus infections in mite-infested colonies that are effectively treated against the mite, and not showing any obvious symptoms. It is reasonable to believe, however, that virus infections do influence colony vitality long before the colony dies.

\section{ACKNOWLEDGMENTS}

We thank Brenda Ball for supplying antisera and the original APV isolate. Many department colleagues had valuable comments on this 
manuscript, likewise a special thanks goes to Brenda Ball. This work was supported by the Nordic Joint Committee of Agricultural Research (NKJ) project no. 86, and received financial support from the agricultural research councils in the participating countries.

\section{Résumé - Infections virales chez des colonies d'abeilles nordiques (Apis mel- lifera $\mathbf{L}$.) nullement, faiblement ou forte- ment infestées par Varroa jacobsoni.} Actuellement nous ne connaissons pas en Europe de colonies d'abeilles où l'on puisse laisser la population d'acariens V. jacobsoni se développer librement sans que celleci n'occasionne des dégâts aux colonies. Il est de plus en plus évident que la cause de l'effondrement des colonies n'est pas due directement à l'infestation par l'acarien, mais due plutôt aux infections virales que l'on sait, ou suppose, être liées à $V$. jacobsoni $[2,8,10,11]$. Le virus de la paralysie aiguë (APV) a été trouvé dans différents pays dans des colonies fortement infestées [2]. On n'a pourtant jamais montré sur le terrain que l'APV causait la mort des colonies s'il n'y avait pas d'infestation simultanée par $V$. jacobsoni $[2,6]$. La présence de plus en plus fréquente dans les colonies infestées d'abeilles ayant des ailes non développées ou déformées a été associée à l'infection par le virus des ailes difformes (DWV) [13]. Ce virus a été trouvé dans des colonies fortement infestées en Europe, Afrique et Asie [2] et sa présence à été mise en relation avec l'effondrement de colonies fortement infestées par l'acarien au Royaume-Uni [17]. Cette étude vise à rechercher la fréquence des virus dans les colonies nullement, faiblement ou fortement infestées de huit ruchers répartis dans les pays nordiques. Deux ruchers expérimentaux totalisant 13 colonies ont été établis en 1994, dans lesquels on a laissé la population d'acariens se développer librement jusqu'à la mort des colonies. Cinq ruchers avec une infestation faible ou contrôlée et un rucher non infesté ont été également échantillonnés durant un an au moins. Le taux de mort naturelle de l'acarien a été suivi dans toutes les colonies expérimentales. Des échantillons d'abeilles vivantes ont été prélevés tous les mois et neuf virus différents ont été recherchés par immunodiffusion. Des abeilles mortes d'un rucher fortement infesté (Gotland) ont été prélevées tous les mois durant l'année de l'effondrement de la colonie. Des analyses sérologiques pour détecter les virus ont été effectuées sur un total de 411 échantillons d'abeilles provenant de 42 colonies. On n'a trouvé aucun dégât ni aucun symptôme de maladie dans aucun des six ruchers qui étaient faiblement ou pas du tout infestés et les seuls virus détectés dans ces ruchers étaient le virus (CWV) et le virus (BQVC) (tableau I). Le virus le plus fréquemment détecté chez les abeilles vivantes dans tous les ruchers a été le CWV. Dix pour cent environ des échantillons d'abeilles vivantes étaient positifs à l'antisérum du CWV et cinq des ruchers avaient au moins une colonie présentant des quantités détectables de ce virus à chaque échantillonnage en 1994. La détection du CWV chez les abeilles vivantes était néanmoins indépendante de la taille de la population d'acariens et, dans cette étude, on n'a pas pu montrer d'étroite relation entre la présence du virus et l'effondrement des colonies. Dans l'une des colonies fortement infestées (Gotland) on a trouvé le DWV associé à l'effondrement de la colonie (tableaux I et $I I$ ). Dans ce rucher infesté de façon variable mais forte, sept des huit colonies sont mortes (figure 1a). Toutes les colonies de ce rucher ont eu au moins un échantillon d'abeilles mortes infecté avec le DWV et dans certaines colonies on a pu détecter le virus dans les échantillons d'abeilles vivantes, plusieurs semaines ou même plusieurs mois avant l'effondrement total (tableau II). Lorsque dans ce rucher certains niveaux de mortalité des acariens étaient atteints, les échantillons des abeilles vivantes et des abeilles mortes avaient toujours une réaction positive au DWV (figure 2). Pourtant les colonies avec une faible mortalité d'acariens pouvaient elles aussi avoir des échantillons positifs au 
DWV. Dans le second rucher dont les colonies se sont effondrées (Skoven), les cinq colonies sont mortes en l'espace de deux ans après l'infestation initiale et le rucher était fortement infesté (figure $1 b$ ). Dans ce rucher, le seul virus détecté dans les échantillons d'abeilles vivantes en relation avec la mort des colonies a été l'APV, mais il n'a été détecté que dans une seule colonie (tableau I). Cette étude a permis d'ajouter les virus suivants à la liste des virus de l'abeille détectés dans les colonies d'abeilles des pays nordiques ; Danemark : CWV et BQCV ; Finlande : aucun ; Norvège : CWV ; Suède : DWV et CWV. ( Inra/DIB/AGIB/ Elsevier, Paris

\section{Apis mellifera / virose / Varroa jacobsoni / effondrement des colonies / virus des ailes difformes}

\section{Zusammenfassung - Virusinfektionen in skandinavischen Honigbienenvölkern mit keinem, niedrigem oder hohem Befall durch Varroa jacobsoni. Zur Zeit gibt es} in Europa nach unseren Kenntnissen keine Bienenvölker, in denen sich Milbenpopulationen frei entwickeln können, ohne die Völker zu schädigen. Allerdings gibt es vermehrt Hinweise, dass der eigentliche Grund für das Zusammenbrechen der Bienenvölker nicht eine direkte Folge des Milbenbefalls ist, sondern dass dieser wahrscheinlich auf Virusinfektionen zurückzuführen ist, von denen man entweder wei $\beta$ oder annimmt, dass sie mit dem Befall durch $V$. jacobsoni assoziiert sind $[2,8,10,11]$. In verschiedenen Ländern wurde der Akute Paralyse Virus (APV) in hochbefallenen Bienenvölkern gefunden [2]. Es wurde aber niemals nachgewiesen, dass APV ohne gleichzeitigen Befall durch $V$. jacobsoni im Freiland eine Todesursache für Honigbienen darstellt $[2,6]$. Das zunehmende Auftreten von Arbeiterinnen mit deformierten Flügeln in milbenbefallenen Völkern wurde mit dem Deformierten Flügel Virus (DWV) in Verbindung gebracht [13]. Dieses Virus wurde in hochbefallenen Völkern in Europa, Afrika und Asien gefunden [2], in Großbritannien wurde es mit dem Zusammenbruch von Völkern in Verbindung gebracht [17]. Die vorliegende Studie untersucht das Vorkommen von Viren in Honigbienenvölkern ohne, mit niedrigem oder mit hohem Befall in acht über die skandinavischen Länder verteilten Bienenständen. 1994 wurden zwei Versuchsstände mit insgesamt 13 Völkern aufgestellt, in denen sich die Milbenpopulationen bis zum Zusammenbruch der Völker frei entwickeln konnten. Zusätzlich wurden in mindestens einem Jahr aus fünf weiteren Bienenstände Proben genommen, diese hatten einen entweder natürlicherweise oder durch Behandlung erzeugten niedrigen Milbenbefall. In allen Versuchsvölkern wurde der natürliche Milbentotenfall monatlich ermittelt. Proben von lebenden Bienen wurden monatlich gesammelt und mit Immunodiffusion auf neun verschiedene Virenarten untersucht. In einem der hochbefallenen Bienenstände (Gotland) wurden in dem Jahr, in dem die Völker eingingen, zu den gleichen Zeiten Proben mit toten Bienen genommen. Insgesamt wurden 411 Bienenproben aus 42 Völkern serologisch auf Viren untersucht. In keinem der Bienenstände ohne oder mit niedrigem Befall durch V. jacobsoni konnten Krankheitssymptome festgestellt werden; die einzigen in diesen sechs Ständen gefundenen Viren waren das Trübe Flügel Virus (CWV) und das Virus der Schwarzen Königinnenzellen (BQCV) (Tabelle I). Das häufigste Virus in Proben von lebenden Arbeiterinnen war CWV (Tabelle I). Etwa $10 \%$ der Proben mit lebenden Bienen waren positiv für CWV Antiserum und fünf der Bienenstände enthielten 1994 bei jeder Probennahme mindestens ein Volk mit erkennbaren Mengen des Virus. Die Ermittlung von CWV in Proben von lebenden Bienen war allerdings unabhängig von der Größe der Milbenpopulation, und es konnte in dieser Untersuchung kein enger Zusammenhang mit dem Zusammenbruch der Völker festgestellt werden. In einem der hochbefallenen Völker (Gotland) fanden wir DWV im Zusammenhang mit 
dem Zusammenbruch (Tabelle I, II). Sieben von acht Völkern in diesem zwar variabel aber hochbefallenen Bienenstand (Abbildung la) starben. Alle Völker in diesem Bienenstand hatten zumindest eine mit DWV befallene Probe von toten Bienen, und in einigen Völkern konnte das Virus einige Wochen oder sogar Monate vor dem Zusammenbruch der Völker in Proben von lebenden Bienen nachgewiesen werden (Tabelle $I I$ ). Sobald in diesem Bienenstand eine bestimmte Höhe des natürlichen Milbentotenfalls erreicht war, waren die Proben sowohl der lebenden als auch der toten Arbeiterinnen immer positiv für DWV (Abbildung 2). Allerdings kamen auch bei Proben von toten Bienen aus niedrig befallenen Völkern positive Befunde vor. In dem zweiten Bienenstand mit zusammenbrechenden Völkern (Skoven) gingen alle Völker innerhalb von zwei Jahren nach der anfänglichen Milbeninfektion ein, $\mathrm{Zu}$ dieser Zeit waren die Völker hochbefallen (Abbildung $1 b$ ). Das einzige auf diesem Bienenstand in Proben von lebenden Bienen gefundene Virus war APV, es trat aber nur in einem der Völker auf (Tabelle I). Diese Studie fügte folgende Viren zu der Auflistung der in den skandinavischen Ländern gefundenen Honigbienenviren hinzu: Dänemark: CWV, BQCV; Finnland: keine; Norwegen: CWV; Schweden: DWV, CWV. (C) Inra/DIB/AGIB/Elsevier, Paris

\section{Apis mellifera / Virusinfektionen / Varroa jacobsoni / Volkszusammenbruch / Deformierte Flügel Virus}

\section{REFERENCES}

[1] Allen M.F., Ball B.V., Characterization and serological relationships of strains of Kashmir bee virus, Ann. Appl. Biol. 126 (1995) 47l-484.

[2] Allen M.F., Ball B.V.. The incidence and world distribution of honey bee viruses, Bee World 77 (1996) 141-162.

[3] Allen M.F., Ball B.V., White R.F., Antoniw J.F., The detection of acute paralysis virus in Varroa jac obsoni by the use of a simple ELISA, J. Apic. Res. 25 (1986) 100-105.
[4] Bailey L.. Paralysis of the honey bee, Apis mellifera Linnaeus, J. Invertebr. Pathol. 7 (1965) $132-140$.

[5] Bailey L., Ball B.V., Honey bee Puthology, 2nd ed., Academic press, London, 1991.

16] Bailey L.. Ball B.V.. Perry J.N., The prevalence of viruses of honey bees in Britain, Ann. Appl. Biol. 97 (1981) 109-118.

[7] Bailey L., Ball B.V., Perry J.N., Association of viruses with two protozoal pathogens of the honey bee, Ann. Appl. Biol. 103 (1983) 13-20.

[8] Ball B.V., The association of Varroa jacobsoni with virus diseases of honey bees, in: Cavalloro R. (Ed.), Varroa jacobsoni Oud. Affecting Honey bees: Present Status and Needs. A. A. Balkema, Wageningen, 1983, pp. 21-23.

[9] Ball B.V., Acute paralysis virus isolates from honey bee colonies infested with Varroa jacobsomi, J. Apic. Res. 24 (1985) 115-119.

[10] Ball B.V., Varroa and viruses, in: Munn P., Jones R. (Eds.), Varroa! Fight the Mite. IBRA, Cardiff, 1997, pp. 11-15.

111] Ball B.V., Allen M.F., The prevalence of pathogens in honey bee (Apis mellifera) colonies infested with the parasitic mite Varroa jacobsomi, Ann. Appl, Biol. 113 (1988) 237-244.

[12] Batuev Y.M., |New information about viral paralysis], Pchelovodstvo 59 (1979) 10-11.

[13] Bowen-Walker P.L., Martin S., Gunn A., The transmission of deformed wing virus between honey bees (Apis mellifera L.) by the ectoparasitic mite Varroa jacobsoni Oud.. J. Invertebr. Pathol. 73(1999) 101-106.

[14] Hornitzky M.A.Z., Prevalence of virus infections of honey bees in Eastern Austrulia, J. Apic. Res. 26 (1987) 181-185.

|I5| Hung A.C.F., Ball B.V., Adams J.R., Shimanuki H., Knox D.A., A scientific note on the detection of American strains of acute paralysis virus and Kashmir bee virus in dead becs in one US honey bee (Apis mellifera L.) colony, Apidologie 27 ( 1996 ) 55-56.

[16] Mansi W., Slide gel diffusion precipitin test, Nature 181 (1958) 1289-1290.

117] Martin S., Hogarth A., van Breda J., Perrett J., A scientific note on Varroa jacobsoni Oudemans and the collapse of Apis mollifera $\mathrm{L}$. colonies in the United Kingdom, Apidologie 29 (1998) 369-370.

[18] Ouchterlony O.. Handhook of Immunodiffusion and Immunoclectrophoresis, Ann Arbor Science Publishers Inc., Ann Arbor, 1968.

1.19| Varis A.L., Ball B.V., Allen M.F., The incidence of pathogens in honey bee (Apis mellifera L.) colonies in Finland and Great Britain, Apidologie 23 (1992) 133-137 